\title{
Study of Cable Force of Construction Control and Alignment Control of Main Girders for Long-Span Railway Cable-Stayed Bridges
}

\author{
Zengshun Chen ${ }^{1}$, Cheng Zhang ${ }^{1}$, Jianting Zhou ${ }^{1}$, Jun Song ${ }^{1} \&$ Chunrong Huang ${ }^{2}$ \\ ${ }^{1}$ School of Civil Engineering \& Architecture, Chongqing Jiaotong University, Chongqing, China \\ ${ }^{2}$ School of Foreign Language, Chongqing Jiaotong University, Chongqing, China \\ Correspondence: Zengshun Chen, School of Civil Engineering \& Architecture, Chongqing Jiaotong University, \\ Chongqing 400074, China. E-mail: chenzs2007@163.com
}

\author{
Received: March 28, $2013 \quad$ Accepted: July 11, $2013 \quad$ Online Published: August 16, 2013 \\ doi:10.5539/mas.v7n9p47 URL: http://dx.doi.org/10.5539/mas.v7n9p47
}

\begin{abstract}
Cable force of construction control and alignment control of main girders are key factors for long-span railway cable-stayed bridges. To make both stayed cable force and alignment of main girders under ideal state simultaneously during construction, based on first-order optimum algorithm, this article regards bending strain energy as an objective function, and then the initial tension can be known through iteration. After analyzing the impact of some factors on alignment control of main girders, such as initial tension of stayed cables and construction load, the formula of alignment control about main girders can be obtained. Finally, taking one of the world's largest railway cable-stayed bridges for an example, the article calculates the initial tension of stayed cables, and analyses the effects of some factors on alignment control of long-span railway cable-stayed bridges. It turns out that this method can keep the alignment and internal force of main girders reasonable.
\end{abstract}

Keywords: cable force of construction control, alignment control of main girders, first-order optimum algorithm, initial tension of stayed cables

\section{Introduction}

With the development of railway transportation network, more and more railway bridges have been built. Cast-in-place cantilever method is often used during construction of long-span railway cable-stayed bridges, whose procedures are quite complex (Housner et al., 1999; Wang, Tang, \& Zheng, 2004; Ge, 2003). Establish a reasonable state of a finished bridge, and then it follows the construction state which is based on the outlined construction processes. However, cable force of construction control and alignment control of main girders are the predominant control parameters for reasonable construction states. Therefore, it is an extremely important factor for construction control to handle the cable force of construction control and alignment control of main girders. By means of first-order optimum algorithm, the article establishes cable forces for different construction states. On the basis of simulation for construction processes of spatial nonlinear finite element, different objective functions are set, design variables and state variables are confined, and then the optimum initial tension can be known, thus reasonable state for alignment of main girders after bridges is built can be obtained through analyzing the effects of initial tension and construction load on alignment control of main girders (Tan \& Zhang, 2008; Kasuga, Arai, Breen, \& Furukawa,1995; Xiao \& Xiang,1998; Shi, Wang, Xiang, \& Xu, 2002).

\section{The Establishment of Initial Tension of Stayed Cables (Yang, 2010; Tan \& Zhang, 2008; Dowd et al.,} 2001)

Bending strain energy between main girders and main pylons should be:

$$
Q(F)=\sum_{i=1}^{p} \int_{s} \frac{M\left(F_{i}\right)^{2}}{E I} \mathrm{ds}, \quad i=1,2 \ldots m_{1}
$$

In the formula:

$F_{i}$--the initial tension of stayed cable $\mathrm{i}$;

$m_{1}$--the sum of stayed cables;

$p$--the number of members of bending strain energy between main girders and main pylons; 
$M\left(F_{i}\right)$--bending moment of members after the bridge is built, under the function of initial tension $F_{i}$;

$I$--the bending moment of inertia on the cross section of members;

$E$--the bending elastic modulus of materials;

$s$--the length of arc after the deformation of girders and pylons;

To optimize cable force of construction control, there always exists a group of the most reasonable initial tensile cable forces $F_{i}$, making bending strain energy $Q(F)$ the least after the bridge is built. Supposing that the objective function of constraint is as follows:

$$
\begin{cases}\min Q(F) & \\ \text { s.t. } \quad F_{i_{\min }} \leq F_{i} \leq F_{i_{\max }} & i=1,2 \ldots m_{1} \\ \sigma_{j_{\min }} \leq \sigma_{j} \leq \sigma_{j_{\max }} & j=1,2 \ldots m_{2}\end{cases}
$$

In the formula, $F_{i_{\min }}, F_{i_{\max }}$ are respectively the upper and lower limit for the initial tension of stayed cables. $\sigma_{j}$ $\sigma_{j_{\min }} \sigma_{j_{\max }}$ are stress and allowable stress of control points for main girders or main pylons respectively, while $m_{2}$ is the sum of stress control points.

Based on the first-order optimum algorithm, multivariable nonlinear programming problem which has constraints can be transferred into nonlinear programming problem without any constraint, that is, the original objective function can be augmented to be a new function:

$$
\Phi\left(F, q_{n}\right)=\frac{Q(F)}{Q(0)}+q_{n}\left[\sum_{i=1}^{m_{1}} P_{F}\left(F_{i}\right)+\sum_{j=1}^{m_{2}} P_{\sigma}\left(\sigma_{j}\right)\right]
$$

In the formula: $\Phi$ is a function without constraints and dimensions; $P_{F}$ is penalty function that is confined by design variables $P_{F} ; P_{\sigma}$ is penalty function that is confined by state variables $\sigma_{j} ; q_{n}$ is penalty factor, which plays a key role on the degree of satisfaction for constraints; $Q(0)$ is the bending strain energy between main girders and main pylons when there is no initial tension on stayed cables.

As for the design variables and state variables with upper and lower limit, their penalty functions can be:

$$
P_{F}\left(F_{i}\right)=\left(\frac{F_{i}}{F_{i_{\min }}-\alpha_{i}}\right)^{2 \lambda}+\left(\frac{F_{i}}{F_{i_{\max }}+\alpha_{i}}\right)^{2 \lambda}
$$

Among them, $\lambda= \begin{cases}10^{6} & F_{i}<F_{i_{\min }} \text { or } F_{i}>F_{i_{\max }} \\ 10^{-6} & F_{i_{\min }} \leq F_{i} \leq F_{i_{\max }}\end{cases}$

$$
P_{\sigma}\left(\sigma_{j}\right)=\left(\frac{\sigma_{j}}{\sigma_{j_{\min }}-\beta_{j}}\right)^{2 \lambda}+\left(\frac{\sigma_{j}}{\sigma_{j_{\max }}+\beta_{j}}\right)^{2 \lambda}
$$

And $\lambda= \begin{cases}10^{6} & \sigma_{j}<\sigma_{j_{\min }} \text { or } \sigma_{j}>\sigma_{j_{\max }} \\ 10^{-6} & \sigma_{j_{\min }} \leq \sigma_{j} \leq \sigma_{i_{\max }}\end{cases}$

In the Formulas (3) \& (4), $\alpha_{i} \beta_{i}$ are the admissible errors of constraints.

To speed up the convergence rate of calculating, penalty coefficient $q_{n}$ ranges from 0.1 to 1.0 and meets the condition: $q_{1}<q_{2}<\ldots<q_{n}$

Based on conjugation method, the search direction of design variables can be identified, and the negative gradient of initial value $-\nabla \Phi\left(F^{0}, q_{0}\right)$ can be regarded as initial conjugation vector $d_{0}$, then the conjugation direction of iteration point i can be established by the following formula:

$$
d^{n}=-\nabla \Phi\left(F^{n}, q_{n}\right)+r^{n-1} d^{n-1}
$$

In the formula, $F^{n}$ is obtained from one-dimensional search according to optimal steps; $-\nabla \Phi\left(F^{0}, q_{0}\right)$ is the negative gradient on $F_{n} ; r^{n-1}$ is the combination coefficient.

After the search direction is obtained, next iteration points can be known by one-dimensional linear search: 


$$
F^{n+1}=F^{n}+\lambda_{n} d^{n} \quad 0 \leq \lambda_{n} \leq \frac{\lambda_{\max }}{100} \lambda_{n}^{*}
$$

Among them, $\lambda_{n}$ is the step size of search; $\lambda_{\max }$ is the largest times of iteration; $\lambda_{n}^{*}$ is the most possible sub iteration. After $F^{n+1}$ is gotten, we can judge whether the point is reasonable or not, based on the following principle:

$$
\left|Q\left(F^{n+1}\right)-Q\left(F^{n}\right)\right| \leq \tau
$$

And it should meet the condition of $F_{i_{\min }} \leq F_{i} \leq F_{i_{\max }}, \sigma_{j_{\min }} \leq \sigma_{j} \leq \sigma_{j_{\max }} . \tau$ is the convergence coefficient.

If not, a new search direction $d_{n}$ can be known, then the iteration should be continued until the convergence exists.

\section{Alignment Control of Main Girders}

Except initial tension of stayed cables, there are still several factors affecting alignment of main girders after bridges are built. Table 1 summarizes influential factors of reasonable alignment control for long-span railway cable-stayed bridges, just as follows (Chen et al., 2013; Li, 2010; Zhang, 2004):

\begin{tabular}{|c|c|c|c|c|}
\hline Alignmen & f Main girder & Influential factors & $\begin{array}{l}\text { Direction of camber } \\
\text { installation }\end{array}$ & $\begin{array}{l}\text { Method of camber } \\
\text { installation }\end{array}$ \\
\hline \multirow{9}{*}{$\begin{array}{l}\text { Alignment } \\
\text { of main } \\
\text { girder }\end{array}$} & \multirow{7}{*}{$\begin{array}{l}\text { Alignment } \\
\text { during } \\
\text { construction }\end{array}$} & Weight of structures & Upward & \multirow{7}{*}{$\begin{array}{l}\text { Sequential analysis, } \\
\text { simulation of construction } \\
\text { processes, as well as } \\
\text { piecewise overlay } \\
\text { analysis }\end{array}$} \\
\hline & & Pre-stress & Downward & \\
\hline & & Initial tension of stays & upward/downward & \\
\hline & & Secondary dead load & upward & \\
\hline & & $\begin{array}{l}\text { Shrinkage and creep in } \\
\text { early period }\end{array}$ & upward/downward & \\
\hline & & $\begin{array}{l}\text { Temporary load(moving } \\
\text { baskets, wet weight) }\end{array}$ & upward & \\
\hline & & $\begin{array}{c}\text { Other } \\
\text { factors(temperature, } \\
\text { deformation of piers) }\end{array}$ & upward/downward & \\
\hline & \multirow{2}{*}{$\begin{array}{l}\text { Alignment after } \\
\text { bridges being } \\
\text { built }\end{array}$} & $\begin{array}{c}\text { Shrinkage and creep in } \\
\text { later period }\end{array}$ & Upward/downward & \multirow{2}{*}{$\begin{array}{l}\text { Analytic method } \\
\text { combining formula and } \\
\text { empirical method }\end{array}$} \\
\hline & & $1 / 2$ live load & upward & \\
\hline
\end{tabular}

Table 1. Influential factors of appropriate cambers installation for long-span railway cable-stayed bridge

\subsection{Influential Factors of Camber Installation for Long-Span Railway Cable-Stayed Bridges (Chen et al., 2013)}

In the process of construction for cable-stayed bridges, installation of cambers is affected by a variety of factors, including: weight of concrete, pre-stress, force produced by stays, deformation of moving basket, shrinkage and creep in the process of construction, secondary dead load.

1) The following formula which can be used to calculate the effect on camber installation caused by concrete weight.

$$
\left[\begin{array}{ccccc}
\delta_{11} & \delta_{12} & \delta_{13} & \cdots & \delta_{1 n} \\
0 & \delta_{22} & \delta_{23} & \cdots & \delta_{2 n} \\
0 & 0 & \delta_{33} & \cdots & \delta_{3 n} \\
0 & 0 & 0 & \cdots & \delta_{4 n} \\
0 & 0 & 0 & 0 & \delta_{n n}
\end{array}\right]\left[\begin{array}{l}
1 \\
1 \\
1 \\
1 \\
1
\end{array}\right]=\left[\begin{array}{c}
\Delta_{1} \\
\Delta_{2} \\
\Delta_{3} \\
\cdots \\
\Delta_{n}
\end{array}\right]
$$

In the formula, $\delta_{i j}$ denotes the deformation value which phrase $\mathrm{j}$ applies on phrase $\mathrm{i}$ and $\Delta_{i}$ denotes deformation value of accumulative weight in section $i$.

2) Analysis about the effect of pre-stressing force 
Assuming that effective pre-stress through a cross-section is $F_{1}, F_{2}, F_{3} \cdots F_{n}$, the distance between pre-stress and neutral axis is $h_{1}, h_{2}, h_{3} \cdots h_{n}$. According to structural mechanics, bending moment acting on differential element $\mathrm{d}(\mathrm{x})$ is:

$$
M(x)=\sum_{i=1}^{n} F_{i} h_{i}
$$

Thus the deflection value of pre-stress acting on differential element $\mathrm{d}(\mathrm{x})$ is:

$$
f=\int \frac{M(x)+\overline{M(x)}}{E(x) I(x)} d(x)
$$

3) Analysis about the effect of initial tension

While being tensioned, stays will produce a group of inclined upward forces on segments, which, under initial tension, will produce upward deflection whose value can be calculated through structural mechanics. And then reverse the value when installing cambers.

4) Analysis about the effect of secondary dead load

Under secondary dead load, main girder can produce downward deflection, which load on beam elements can simulate. After calculating its deflection, we just reverse it when installing camber.

5) Analysis about shrinkage and creep in early period

In practical situations, creep, shrinkage as well as temperature strain are not isolated while happen together. Generally speaking, temperature stress and strain should analyze singly while shrinkage and creep should be calculated together, which we can refer to standard specification of CEP-FIP (1990) and Specification for design of highway reinforced concrete and pre-stressed concrete bridges and culverts.

6) Analysis about the effect of temporary load during construction (moving hanging baskets, braces etc.)

Under combined action of weight of moving hanging baskets, braces etc. and weight of segments, moving hanging baskets and braces will produce elastic deformation and none-elastic deformation, whose force can be calculated by tests. When installing camber, we should take these two parts into account.

7) Analysis about the effect of temperature

Temperature will inevitably affect the process of construction and displacement measurement. High temperature will result in error, so lower temperature and stabilized time period are better choices in practice. Additionally, to decrease the effect of temperature on camber installation, we can measure it repeatedly, and then know its law.

8) Analysis about construction load

Construction load will be removed in later period, which may result in compression of piers and deformation of moving baskets etc.. We should eliminate such impact when installing camber.

\subsection{Installation Method of Alignment for Main Girders}

Camber installation after bridges being built is mainly affected by shrinkage and creep in later period as well as live load after being open to traffic. As for the complexity of the impact of shrinkage and creep on camber installation, we can get it by tests, experiences or theories and generally, combining FEM software--Midas civil2010 and experiences (curve distribution method etc.). The effect of live load on camber after bridges being built can be known by modeling method.

When installing cambers for long-span railway cable-stayed bridges, the above factors should be taken full consideration. Based on results of deflection and recognizing parameters, actual modeling levels can be done after analyzing each influential factor of deflection correctly. As for the "gray part" of influential factors, if not being analyzes correctly, predicative analysis method should be taken, such as gray theory and linear regression method. Design formula of total camber can like this (Chen et al., 2013; Wang, Tang, \& Zheng, 2004; Xiao, 1996; Xiang, 2001; Ge, 2003):

In the formula:

$$
\begin{gathered}
f=f_{i}+f_{c} \\
f_{i}=\sum f_{1 i}+\sum f_{2 i}+f_{3 i}+f_{4 i}+f_{5 i}+f_{6 i}+f_{7 i}+f_{8 i} \\
f_{c}=\alpha d_{1}+\frac{1}{2} d_{2}
\end{gathered}
$$


$f_{i}$ - camber during construction

$f_{c}$ - camber after bridges being built

$\sum f_{1 i}$-total deflection value after the segments finished and in later phrases

$\sum f_{1 i}$-impact value of longitudinal tension pre-stress during this phrase and next phrases

$f_{3 i}$-camber caused weight of structures during construction

$f_{4 i}$-camber caused by pre-stressing load

$f_{5 i}$ - camber caused initial tension of stays

$f_{6 i}$ - camber caused by secondary dead load

$f_{7 i}$-camber caused by shrinkage and creep during construction

$f_{8 i}$ - camber caused by temporary load during construction

$\alpha$-empirical coefficient

$d_{1}$ - deflection value affected by shrinkage and creep after bridges being built for 20 years

$d_{2}$-deflection value of moving load

\section{Case Study}

The main bridge of a long-span railway cable-stayed bridge is a dual-pylon-dual-plane concrete cable-stayed bridge, whose span is $60+135+250+135+60 \mathrm{~m}$. Its tower is a shape of diamond, and about $183 \mathrm{~m}$ in height, as well as its auxiliary piers are hollow with rectangular cross-section. There are totally 56 pairs of stays. The main beam adopts concrete box girder with single-box-single-cell and same height of girders, whose width is $15 \mathrm{~m}$, and height is $3.5 \mathrm{~m}$ (Chen et al., 2013).

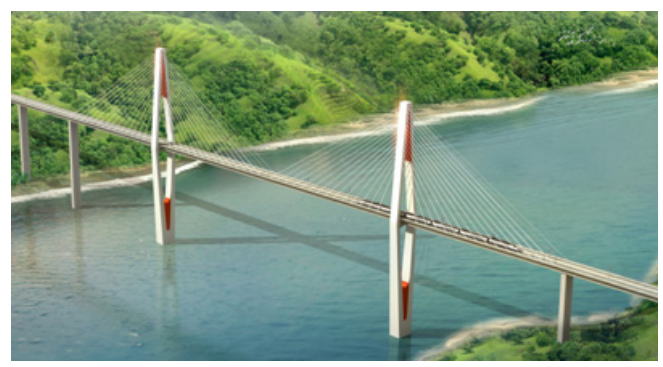

Figure 1. Effect drawing of a long-span railway cable-stayed bridge

\subsection{The Establishment of Initial Tension of Stayed Cables}

4.1.1 Design Variables (Yang, 2010; Tan \& Zhang, 2008; Dowd et al., 2001)

Make cable force $F_{i}$ be design variable, and constraint condition $F_{i_{\min }} \leq F_{i} \leq F_{i_{\max }}$ is applied on $F_{i}$, then the size of $F_{i_{\min }}, F_{i_{\max }}$ should be specified according to practical situations.

4.1.2 State Variables (Yang, 2010; Tan \& Zhang, 2008; Dowd et al., 2001)

In the process of loading on main girders, all stresses of key control points on main girders and main pylons are variables to confine, which are called state variables. Besides, the constraint condition applied on control points is $\sigma_{j_{\min }} \leq \sigma_{j} \leq \sigma_{j_{\max }}$.

\subsubsection{Calculating Results}

After obtaining the Design Variables and State Variables, according to the objective function of bending strain energy, the initial tension can be shown in Figure 2: 


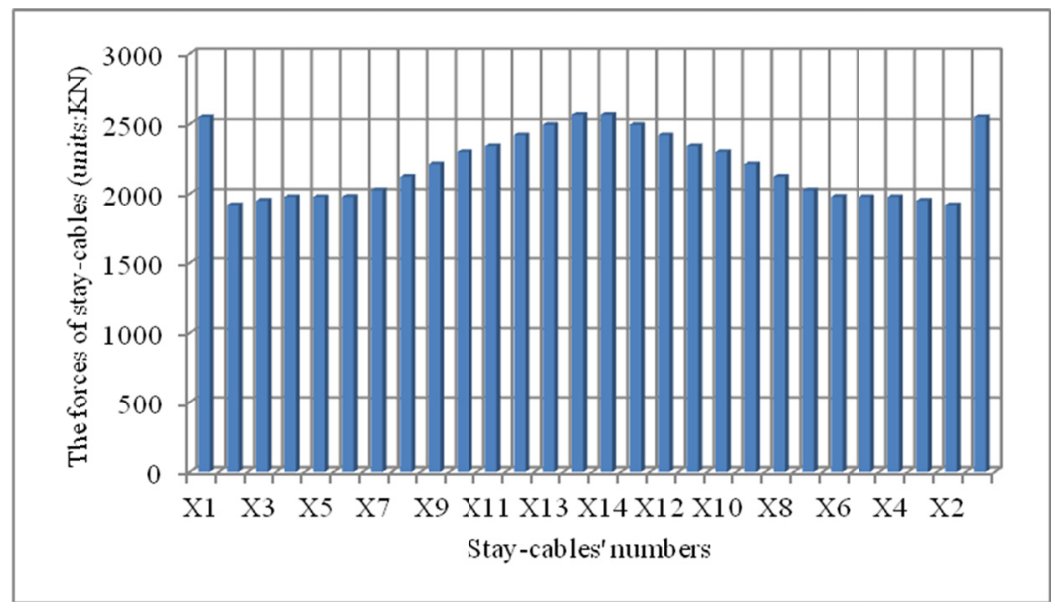

Figure 2. The initial tension ( $\mathrm{X}$ denotes the number of cables, and $\mathrm{KN}$ the unit of cable force)

Initial tension being established, the cable force on secondary cable adjustment is shown in Figure 3:

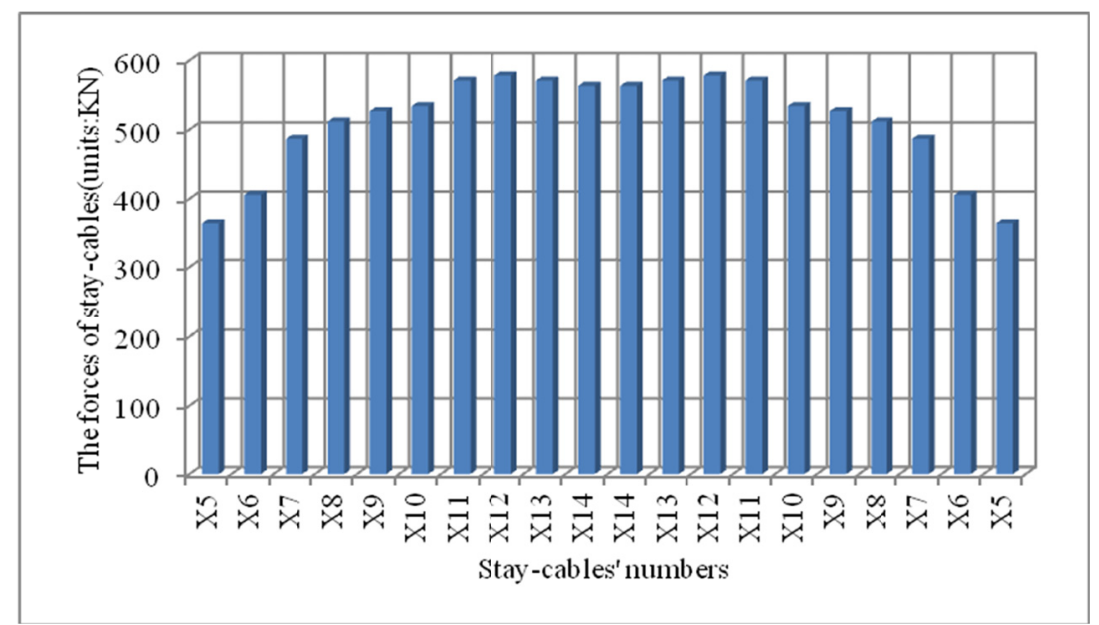

Figure 3 . The cable force on secondary cable adjustment (X denotes the number of cables, and $\mathrm{KN}$ the unit of cable force)

\subsection{Calculating Reasonable Alignment Using Finite Element Software}

After initial tension and secondary cable force are established, taking the influential factors of alignment control of main girders into account, FEM software--Midas civil2010 is exploited among which 819 nodes and 703 units are formed, just shown in Figure 4:

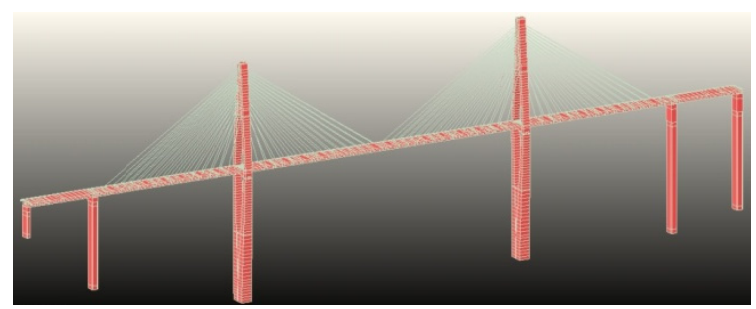

Figure 4. Midas model of a long-span railway cable-stayed bridge

\subsection{Analysis about Calculating Results}

(1) After refining the initial tension of stayed cables, establishing the model by FEM software--Midas civil 2010, after analyzing, the displacement of main girders resulting from initial tension of 14 pairs of stayed cables can be shown in Figure 5: 


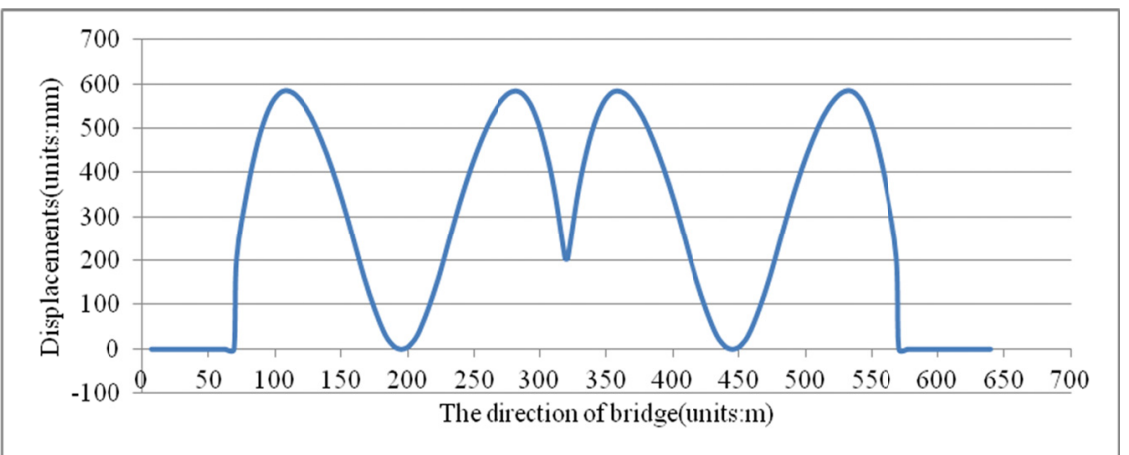

Figure 5. Displacement of main girders resulting from initial tension of stayed cables

(2) Displacement of main girders resulting from temporary load during construction, shown in Figure 6:

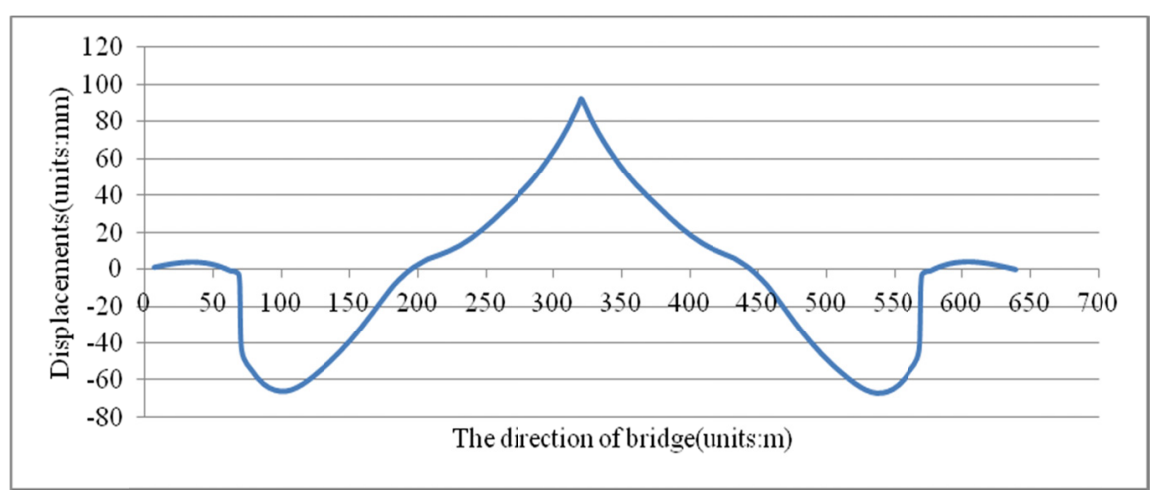

Figure 6. Displacement of main girders resulting from temporary load during construction

(3) Displacement of main girders resulting from secondary dead load, shown in Figure 7:

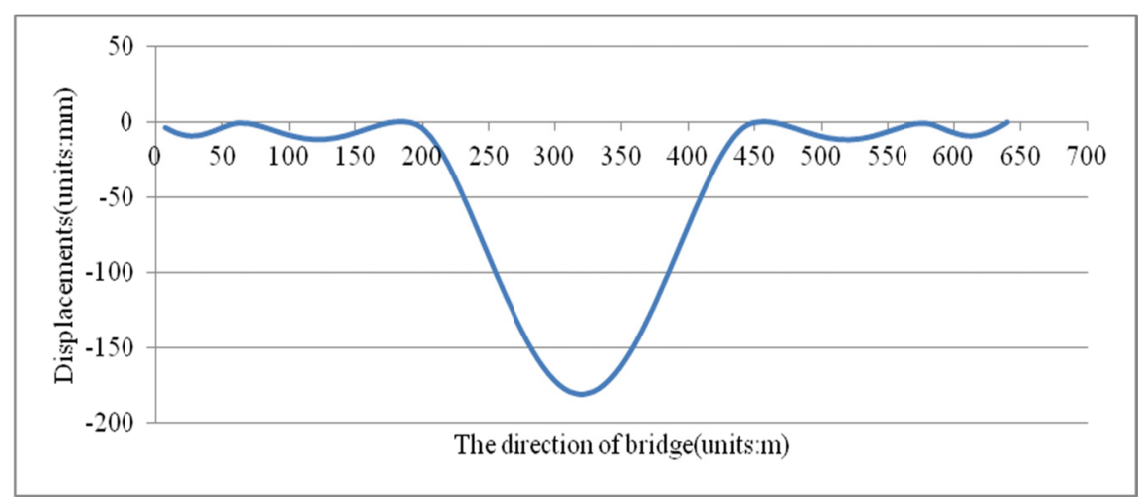

Figure 7. Displacement of main girders resulting from secondary dead load

(4) Displacement of main girders resulting from its own weight, shown in Figure 8: 


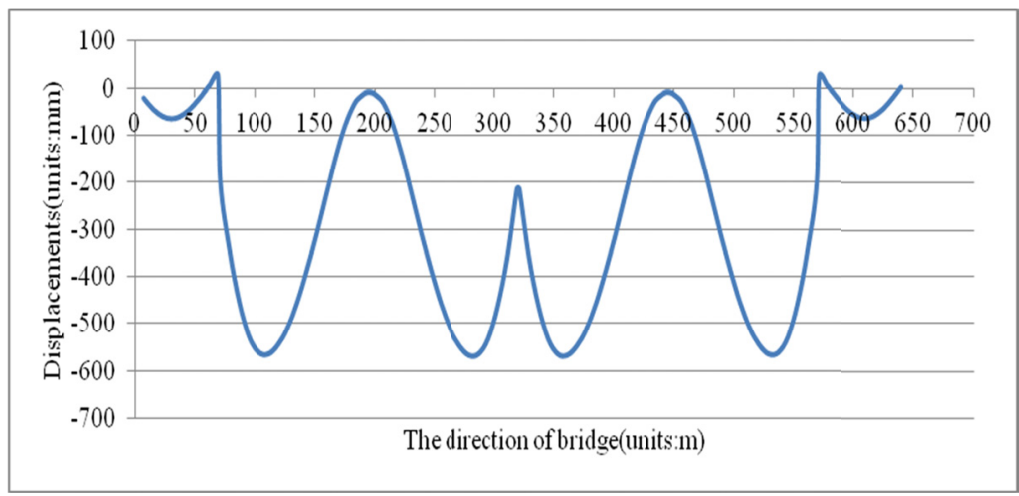

Figure 8. Displacement of main girders resulting from its own weight

(5) Displacement of main girders resulting from secondary cable adjustment, shown in Figure 9:

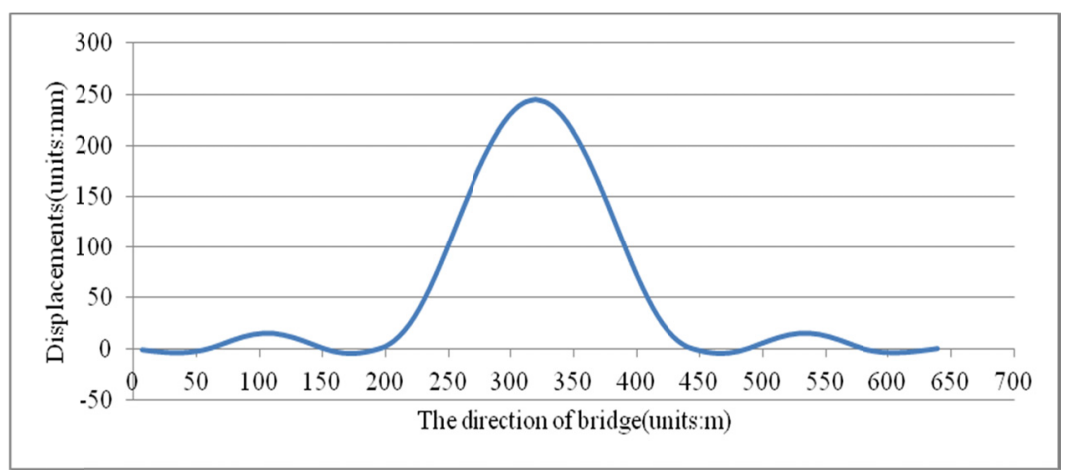

Figure 9. Displacement of main girders resulting from secondary cable adjustment

(6) Displacement of main girders resulting from steel strands, shown in Figure 10:

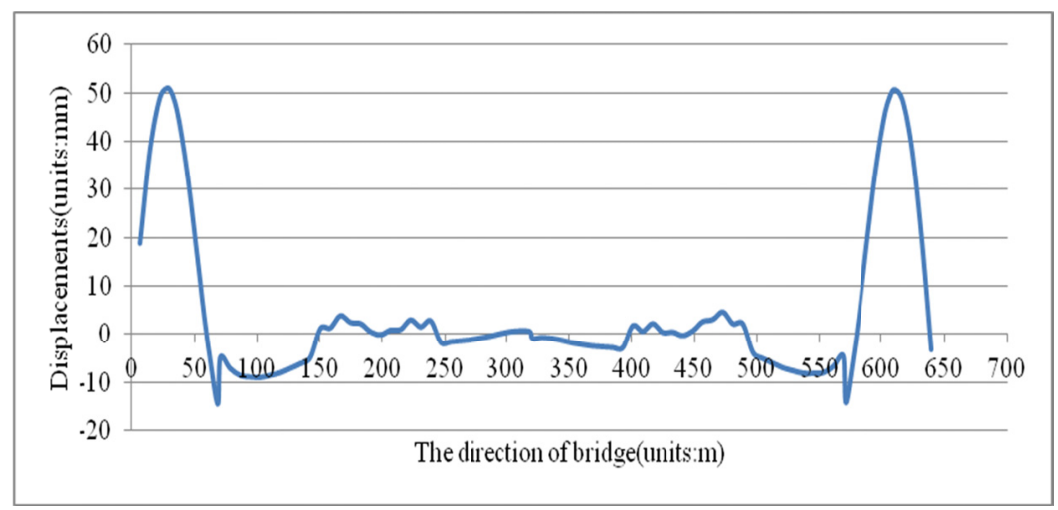

Figure 10. Displacement of main girders resulting from steel strands

(7) Displacement of main girders resulting from 1/2 live load, shown in Figure 11: 


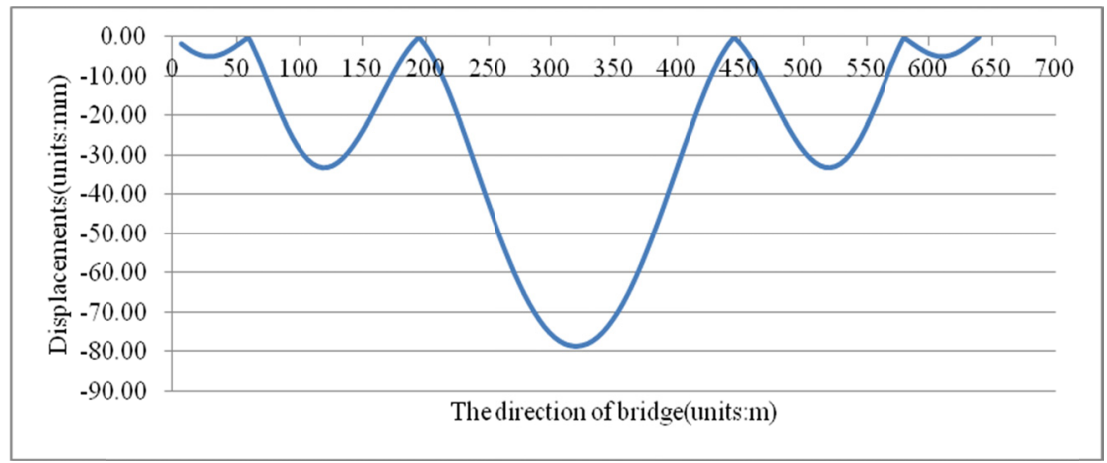

Figure 11. Displacement of main girders resulting from $1 / 2$ live load

(8) Displacement of main girders resulting from shrinkage and creeping, shown in Figure 12:

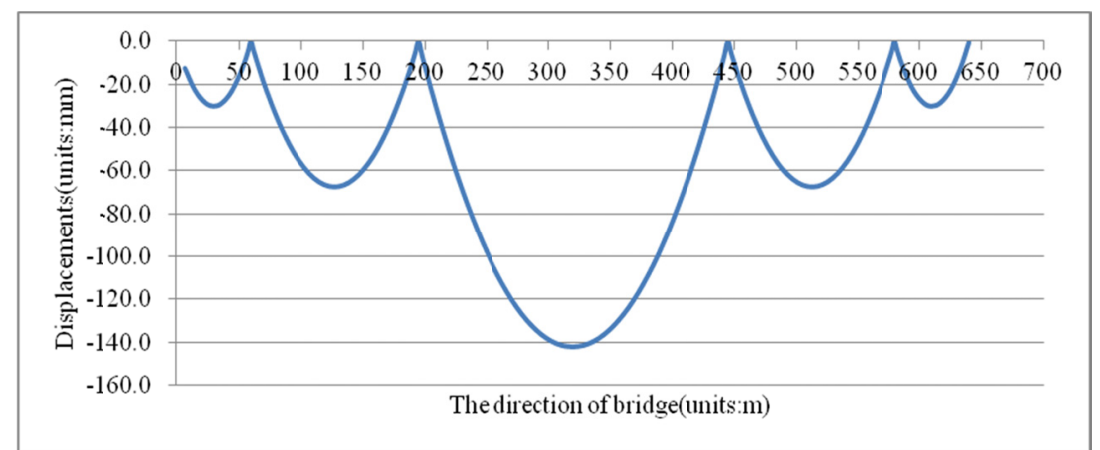

Figure 12. Displacement of main girders resulting from shrinkage and creeping

From Formula 8, displacement of main girders after bridges are built consists of temporary load during construction, weight of structures, secondary dead load, pre-stress, force of stayed cables, shrinkage and creeping, as well as moving load. Therefore, the total displacement of main girders after bridges are built is as Figure 13:

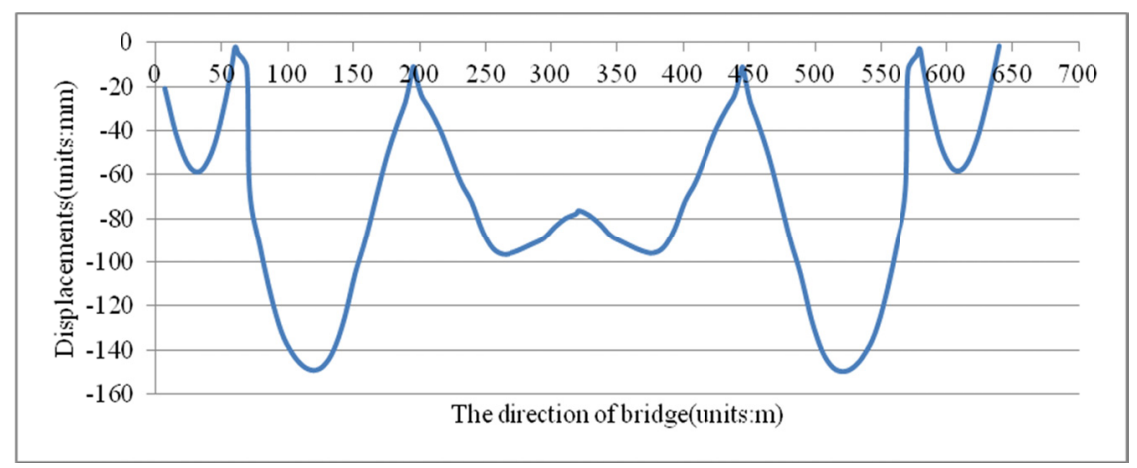

Figure 13. The total displacement of main girders after bridges are built

When controlling the alignment of main girders, we should reverse the displacement of main girders, namely, the alignment of main girders after bridges are built. This method has been employed in practice, which shows that in the process of cantilever construction, the alignment of main girders changes a lot, while error between theoretical level and vertical design alignment is quite small. What's more, according to some key construction processes, it is known that the largest tensile stress in the process of box girder's construction is $0.9 \mathrm{Mpa}$, and the largest compression stress is $9.52 \mathrm{Mpa}$, which satisfies the specification (in Specification, admissible tensile stress is $2.1 \mathrm{Mpa}$, and admissible compression stress is $28.0 \mathrm{Mpa}$ ).

\section{Conclusion and Vision}

1) Using first-order optimum algorithm can make alignment of main girders and internal force under reasonable control, and make conjugation rate of iteration quick, which demonstrates that this method is effective for 
establishing reasonable construction state;

2) When the method for cable force of construction control and alignment control being applied on construction control of a long-span railway cable-stayed bridge, it is shown that this method is reliable and is of high practical applications;

3) As for concrete railway cable-stayed bridges with main girders of high stiffness, internal force and alignment control should be paid great attention in the process of construction;

4) It is rather complex that shrinkage and creeping of concrete affect long-span railway cable-stayed bridges, which can be further studied through experiments;

5) Taking into consideration the differences between long-span railway cable-stayed bridges and highway cable-stayed bridges, more researches should be carried out about reasonable alignment control of long-span railway cable-stayed bridges.

\section{References}

Chen, Z., Song, J., Zhang, C., Huang, G., \& Wei, H. (2013). Study of Different Construction Processes Affecting the Installation of Appropriate Cambers for Long-Span Railway Cable-Stayed Bridges. Modern Applied Science, 7(8), 89-96. http://dx.doi.org/10.5539/mas.v7n8p89

Dowd, J., Poser, M., Frank, K., Wood, S., \& Williamson, E. (2001). Bending Fatigue of Cable Stays. Journal of Bridge Engineering, 2001, 639-644. http://dx.doi.org/10.1061/(ASCE)1084-0702(2001)6:6(639)

$\mathrm{Ge}, \mathrm{Y}$. (2003). Section analysis and construction control of bridge. Beijing: China Communications Press.

Housner, G. W., Bergman, L. A., Caughey, T. K., Chassiakos, A. G., Claus, R. O., Masri, S. F., .. Yao, J. T. P. (1997). Structural control: Past, present, and future. Journal of Engineering Mechanics, 123(9), 897-971. http://dx.doi.org/10.1061/(ASCE)0733-9399(1997)123:9(897)

Kasuga, A., Arai, H., Breen, J., \&Furukawa, K.(1995). Optimum Cable-Force Adjustments in Concrete Cable-Stayed Bridges. Journal of Structural Engineering, 121(4), 685-694.

Li, G. (2010). Study on construction of PC cable-stayed bridge control of main beam. Master Dissertation of Chang' an University.

Shi, D., Wang, J., Xiang, Y., \& Xu, X. (2002). Optimum tensioning in construction state of cable-stayed bridge. China Journal of Highway and Transport.

Tan, H., \& Zhang, J. (2008). Cable prestress and alignment double control during construction of large-spancable-stayed bridges. Joumal of Hehai University (Natural Sciences).

Wang, P., Tang, T., \& Zheng, H. (2004). Analysis of cable-stayed bridges during construction by cantilever methods. Computers \& Structures. http://dx.doi.org/10.1016/j.compstruc.2003.11.003

Xiang, H. (2001). Advanced theory of bridge structures. Beijing: China Communications Press.

Xiao, R. (1996). Study on design theory and method of determining reasonable state of long-span bridge structure. Doctoral dissertation of Tongji University.

Xiao, R., \& Xiang, H. (1998). Optimization method of cable pre-stresses of cable-stayed bridges and its engineering applications. Chinese Journal of Computational Mechanics.

Yang, J. (2010). Determining the Rational Completion Cable Forces Based on Influence Matrix Method United Minimum Bending Energy Method. Traffic and Transportation Studies@2010 ASCE, 1417-1424. http://dx.doi.org/10.1061/41123(383)136

Zhang, J. (2004). No back-stays \& inclined pylon cable-stayed bridge static performance and Research on the reasonable finished dead state. Master Dissertation 1of Changsha University of Science and Technology.

\section{Copyrights}

Copyright for this article is retained by the author(s), with first publication rights granted to the journal.

This is an open-access article distributed under the terms and conditions of the Creative Commons Attribution license (http://creativecommons.org/licenses/by/3.0/). 